\title{
HMGB1: a smoking gun in lupus nephritis?
}

\author{
David S Pisetsky ${ }^{* 1,2}$ \\ See related research by Zickert et al., http://arthritis-research.com/content/14/1/R36/abstract
}

\begin{abstract}
High-mobility group box 1 protein (HMGB1) is a prototypic alarmin that is released from activated and dying cells. Because of its proinflammatory activities, HMGB1 could mediate key events in the pathogenesis of systemic lupus erythematosus, a possibility supported by elevations of HMGB1 in patient blood and increased expression in renal biopsies. The biology of HMGB1 is complicated, however, and its activity is dependent on redox state as well as binding to other molecules such as cytokines. Defining more precisely the role of HMGB1 in lupus will require treatment studies to block the activity of this alarmin in animal models and ultimately patients.
\end{abstract}

A smoking gun is probably the most dramatic and iconic evidence of a crime. The concept of the smoking gun originated in a Sherlock Holmes story and then languished until it exploded into awareness during the impeachment hearings of Richard Nixon. As now understood, a smoking gun is an incontrovertible piece of evidence to establish a crime and even identify the perpetrator. This is especially true if the gun, sulfurous fumes streaming from the barrel, resides in the hand of a suspect, the murder victim bleeding nearby.

In rheumatology as in all of medicine, investigators are forever searching for the smoking guns of pathogenesis. The identification of such guns, especially when found at the crime scene (such as a kidney biopsy), can delineate the mechanism of tissue injury as well as suggest new targets of therapy. Smoking guns in medicine can be very elusive, however, and cold cases abound. Assembling a case beyond a reasonable doubt can require a multitude of in vitro and in vivo studies, including treatment trials in animal models as well as patients.

*Correspondence: dpiset@acpub.duke.edu

'Durham VA Medical Center, Box 151G, 508 Fulton Street, Durham, NC 27705, USA Full list of author information is available at the end of the article
In the previous issue of Arthritis Research \& Therapy, Zickert and colleagues [1] provided important new evidence implicating high-mobility group box 1 protein (HMGB1) as a mediator of lupus nephritis, and the enhanced expression of HMGB1 is perhaps a smoking gun in the pathogenesis of a very complicated disease. As the data presented indicate, levels of HMGB1 are elevated in the blood of patients with lupus nephritis; furthermore, renal biopsies showed increased HMGB1 expression in the mesangium and endothelium. The elevations of HMGB1 in blood occurred in patients with different histopathological forms of lupus nephritis but, interestingly, did not vary much over time or with treatment [1].

These observations are important in view of the biological properties of HMGB1. HMGB1 is a prototype alarmin and, indeed, the prime example of this class of immune mediator. In other terminology, HMGB1 is a DAMP (damage-associated molecular pattern). The immune activities of HMGB1 are perhaps surprising since HMGB1 is a nuclear molecule ubiquitously expressed in cells. In its usual location, HMGB1 can bind DNA as an architectural element for chromatin structure; once released from cells, however, HMGB1 acquires a new identity and displays potent and varied immunological activities. This release can occur during immune cell activation as well as cell death, whether apoptosis or necrosis [2].

Along with other studies on systemic lupus erythematosus [3-5], the evidence for a central role of HMGB1 in lupus pathogenesis is strong but nevertheless circumstantial. One of the difficulties in making the case watertight concerns the complex biology of HMGB1. While HMGB1 has immunological activity, the extent of such activity varies significantly depending on its structure, including the redox state of cysteine (C) residues at positions 23,45 , and 106 . With pure HMGB1, activity requires a $\mathrm{C} 106$ thiol and a $\mathrm{C} 23-45$ disulfide bond to induce activation of nuclear factor-kappa-B. With these modifications, HMGB1 can bind to Toll-like receptor 4 (TLR4) to stimulate responses but the oxidized form lacks such activity [6,7]. Thus, the finding of HMGB1 in the blood or tissue does not prove that it is functionally active. 
A further complexity concerns the manner in which HMGB1 stimulates inflammation. While active by itself depending on redox state, HMGB1 can also function in concert with cytokines such as interleukin-1 (IL-1). These complexes can stimulate responses through the cytokine receptor to dramatically boost immunostimulatory activity $[8,9]$. Similarly, HMGB1 can form complexes with PAMPs (pathogen-associated molecular patterns) such as lipopolysaccharide or CpG DNA to act via a TLR. Thus, the finding of high levels of HMGB1 in the blood or tissue is the beginning, not the end, of the story. In the absence of a partner in crime such as IL-1 or lipopolysaccharide, the effect of this molecule may be limited depending on the status of the cysteines [10].

As is now recognized, HMGB1 emanates from cells during activation, necrosis, and apoptosis. Whereas HMGB1 from activated and necrotic cells has alarmin activity, HMGB1 released during apoptosis may lack such activity because of oxidation [7]. Since tissue injury (for example, ischemia) can lead to apoptosis and therefore HMGB1 release, the presence of extracellular HMGB1 may denote the effects of injury rather than establish the cause. In this regard, HMGB1 can be a component of immune complexes in lupus, likely reflecting its interaction with DNA that emerges from dead or dying cells $[4,5]$. The role of HMGB1 in nephritis as opposed to dendritic cell activation is not yet clear, although, as shown in the current study, the finding of HMGB1 in the mesangium may signify immune deposition; in this case, the activation of the complement system, rather than any direct effect of HMGB1 itself, may be the key event in inciting nephritis.

HMGB1 has generated great interest as a new target of immununosuppressive therapy since, in animal models of shock and arthritis, blocking the action of HMGB1 can be strikingly beneficial [2]. Such studies are awaited in lupus. Only then will it be possible to know whether the HMGB1 gun in lupus nephritis is smoking or just smoldering.

Abbreviations

C, cysteine; HMGB1, high-mobility group box 1 protein; IL-1, interleukin-1; TLR, Toll-like receptor.
Competing interests

The author declares that he has no competing interests.

\section{Acknowledgments}

This work was supported by a VA Merit Review Grant and NIH AI-056363.

\section{Author details}

'Durham VA Medical Center, Box 151G, 508 Fulton Street, Durham, NC 27705, USA. ${ }^{2}$ Duke University Medical Center, Durham, NC 27710, USA.

Published: 14 March 2012

\section{References}

1. Zickert A, Palmblad K, Sundelin B, Chavan S, Tracey KJ, Bruchfeld A, Gunnarsson I: Renal expression and serum levels of high mobility group box 1 protein in lupus nephritis. Arthritis Res Ther 2012, 14:R36.

2. Harris HE, Andersson U, Pisetsky DS: HMGB1: a multifunctional alarmin driving autoimmune and inflammatory disease. Nat Rev Rheumato/ 2012 Jan 31 [Epub ahead of print].

3. Jiang W, Pisetsky DS: Expression of high mobility group protein 1 in the sera of patients and mice with systemic lupus erythematosus. Ann Rheum Dis 2008, 67:727-728.

4. Tian J, Avalos AM, Mao SY, Chen B, Senthil K, Wu H, Parroche P, Drabic S, Golenbock D, Sirois C, Hua J, An LL, Audoly L, La Rosa G, Bierhaus A, Naworth P, Marshak-Rothstein A, Crow MK, Fitzgerald KA, Latz E, Kiener PA, Coyle AJ: Toll-like receptor 9-dependent activation by DNA-containing immune complexes is mediated by HMGB1 and RAGE. Nat Immuno/ 2007, 8:487-496.

5. Urbonaviciute V, Fürnrohr BG, Meister S, Munoz L, Heyder P, De Marchis F, Bianchi ME, Kirschning C, Wagner H, Manfredi AA, Kalden JR, Schett G, Rovere-Querini P, Hermann M, Voll RE: Induction of inflammatory and immune responses by HMGB1-nucleosome complexes: implications for the pathogenesis of SLE. J Exp Med 2008, 205:3007-3018.

6. Yang H, Hreggvidsdottir HS, Palmblad K, Wang H, Ochani M, Li J, Lu B, Chavan S, Rosas-Ballina M, Al-Abed Y, Akira S, Bierhaus A, Erlandsson-Harris H, Andersson $U$, Tracey $\mathrm{KJ}$ : A critical cysteine is required for HMGB1 binding to toll-like receptor 4 and activation of macrophage cytokine release. ProC Natl Acad SciU S A 2010, 107:11942-11947.

7. Yang H, Lundbäck P, Ottosson L, Erlandsson-Harris H, Venereau E, Bianchi ME, Al-Abed Y, Andersson U, Tracey KJ, Antoine DJ: Redox modification of cysteine residues regulates the cytokine activity of HMGB1. Mol Med 2011 Nov 7 [Epub ahead of print].

8. Hreggvidsdottir HS, Ostberg T, Wähämaa H, Schierbeck H, Aveberger AC, Klevenvall L, Palmblad K, Ottosson L, Andersson U, Harris HE: The alarmin HMGB1 acts in synergy with endogenous and exogenous danger signals to promote inflammation. J Leukoc Bio/ 2009, 86:655-662.

9. Garcia-Arnandis I, Guillén MI, Gomar F, Pelletier JP, Martel-Pelletier J, Alcaraz $\mathrm{MJ}$ : High mobility group box 1 potentiates the pro-inflammatory effects of Interleukin-1 $\beta$ in osteoarthritic synoviocytes. Arthritis Res Ther 2010, 12:R165.

10. Pisetsky DS: Cell death in the pathogenesis of immune-mediated diseases: the role of HMGB1 and DAMP-PAMP complexes. Swiss Med Wkly 2011, 141:w13256.

doi:10.1186/ar3754

Cite this article as: Pisetsky DS: HMGB1: a smoking gun in lupus nephritis? Arthritis Research \& Therapy 2012, 14:112. 